\title{
How Local Innovation Systems Empowering Community: Case Study in Belu of East Nusa Tenggara, Indonesia
}

\author{
Savitri Dyah W.I.K.R. ${ }^{1}$ and Rachmini Saparita ${ }^{2}$ \\ ${ }^{1}$ Research Center for Policy and Management of Science, Technology and Innovation \\ Indonesian Institute of Sciences \\ Jakarta , Indonesia \\ Email: savitridyah.sd [AT] gmail.com \\ ${ }^{2}$ Research Center for Policy and Management of Science, Technology and Innovation \\ Indonesian Institute of Sciences \\ Jakarta, Indonesia \\ Email: rsaparita [AT] gmail.com
}

\begin{abstract}
A Local Innovation Systems (LIS) was establish in Bakustulama Village of Esat Nusa Tenggara Province in Indonesia in 2013 and has serve the local people in their productive activity since. This paper was an evaluation of how this LIS play the role on empowering the local peole. The study involved 2 farmer groups to be involved in developing LIS then applied it in their productive activities. Since the implementation LIS has served the two farmer groups in increasing their economic life (income received). LIS was attached to the local agricultural extension office as an institution that consists of farmer groups, local extension workers, staffs from Local Government Offices (Agricultural-Fisheries and Plantation Offices, Local Animal Husbandry Offices, Local Forestry Offices, Sub-District \& Village Offices)and supported by local researchers. The LIS as institutions running well to served the need of the people by establishing networks with other institutions and reserchers from several intitutions available in the area. A chnge in policy from Central Government in 2016 had change the existency of LIS as institution, however the network still function and the people still can benefitted from it, which was shown from the evaluation conducte in 2019. An index number was applied here to measure the change occurs in the two farmer groups before and after the implementation of LIS. Significant changes were occurs in the two farmer groups, they economic life were changes in better way, which is why they still maintaining the network from LIS although the institution was not exist anymore. Here, the LIS was transform into a systems that was run by farmer groups which still maintain the network that was already established.
\end{abstract}

Keywords- economic life, farmer groups, local innovation systems, local institution, network

\section{INTRODUCTION}

A local innovation system has been implemented in Bakustulama Village in Tasifeto Barat Sub-district of Belu District in East Nusa Tenggara Province, Indonesia. Most of the communities are farmers and cattle breeders in 2013. The Local Innovation Systems (LIS) was developed in 2012 by Belu local government (District and Sub-District), Staff of Agriculture Extension Office, Representative of Farmer Groups from Belu District assisted by researchers form Indonesian Institutes of Sciences (IIS). The establishment of LIS was hoping can assist the local government in poverty alleviation. Bakustulama Village choosed as the location of LIS implementation was in consideration that around $50 \%$ of the inhabitant were considered as poor. ${ }^{1}$ It was recognized that a strong local innovation systems could help in poverty alleviation and support the sustainability of rural development (Ximing Yin, Jin Chen, Jizhen Li, 2019). In the Introduction section, present clearly and briefly the problem investigated, with relevant references. The main results should be enunciated.

The LIS implemented was adapting the local condition, socially and environtmentally (Saparita R., Dyah, Mulyadi, \& Hidajat, 2012; Saparita R., Dyah, Abbas, \& Hidajat, 2015). The implementation was taken in 2013, with the aim to empower the local community especially people with relatively low income. Survey on 2012 indicated that around $50 \%$ of people in Bakustulama Village were consided as poor, ave no or lack of access to innovation or technology that can be

\footnotetext{
${ }^{1}$ Information and data gathered by survey and interview with the local government (village) and the extension workers
} 
used to increase their production, productivity, and income, this fact also supported from many studies in rural areas (Berdegué \& Escobar, 2002; McCulloch, Weisbrod, \& Timmer, 2007; Natawidjaya, Bachrein, Sinaga, Perdana, Sugandi, \& Budiman, 2007; Saparita R. , Dyah, Abbas, \& Hidajat, 2015; Mbagwu, Benson, \& Onuoha, 2018). Technology such as hand-tractor, harvester, thresher, water-pump or good cultivation technique etc., can increase production and productivity (Thirtle, 2010; Javed, Farooq, \& Ali, 2010; Parke, 2015; Food and Agriculture Organization, 2016). East Nusa Tenggara (Figure 1) in general has dry climate (semiarid) with short rainy season, usually start from December to March, which also apply to Bakustulama Village as the study area. This condition affected the low production which only enough for own consumption in other word they are subsistence farmers. Although in average people have enough land, around 2-4 ha per household that can provide a decent life (Hermanto, 2017), but because of the condition, they only could cultivate half of their land with the production only enough for own consumption (for rice and corn), and a little production of vegetables to be sell in the local market. The local market is a weekly market near their village. The availability of the market is 5 days a week but operate in different villages with the range between $12 \mathrm{~km}$ to $54 \mathrm{~km}$ from Bakustulama Village. But due to the distance, people of Bakustulama only sell their products in Halelulik Market open on Thursday which located not far from their village, around $12 \mathrm{~km}$. However, the local market could not absorb all products from the farmers. Usually, they sell the rest of their products to the middlemen that come to their village. With this condition increasing their production is unproductive from their point of view, because they could not sell their excess product. Opening access to innovation or technology for poor farmers is very important to increase their production, but it should be supported by market where they can sell their products. With this fact LIS become important tool for farmers to get access to innovation and also market. In 2013 the LIS was applied and focused on poor people and open access to market. The poor farmer as target of the study, is refers to the national poverty line of IDR 440,000/capita/month (Statistic Indonesia, 2020) or equal to US \$18.49. There were two farmer groups in the study, the first group is called the new residents and the second group is the local farmers.

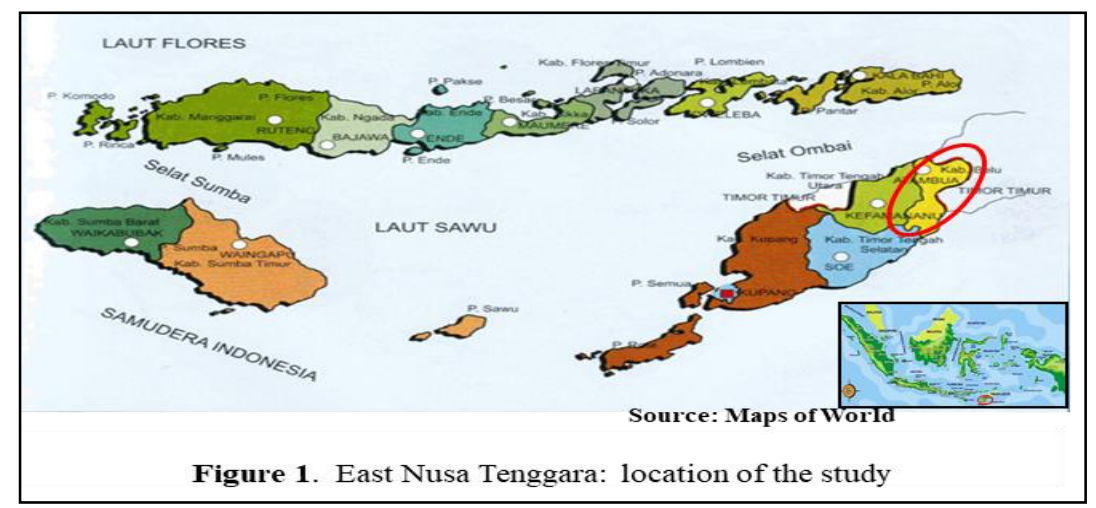

This paper discusses the concept of local innovation system that can support the local government in poverty alleviation. The challenges, especially in rural areas, are environmental and cultural barriers to knowledge creation and dissemination, including poor infrastructure for innovation, underdeveloped transaction markets for innovation as well as community production, less risk-taking, more short-term and vulnerable behavior against poverty. All of these factors in rural areas can hinder innovation, entrepreneurship, and the benefit of technology (Saparita R. , Dyah, Mulyadi, \& Hidajat, 2012; Ximing Yin, Jin Chen, Jizhen Li, 2019). As the LIS here was implemented in rural area, it can be referred to as rural innovation systems, which recently become the attention of innovation systems studies. Without a rural innovation system, there is little chance of achieving sustainable rural development (David J. Spielman, Kristin Davis, Martha Negash \& Gezahegn Ayele, 2011; Saparita R. , Dyah, Abbas, \& Hidajat, 2015). An essential element of rural innovation systems is the rural innovation network. The rural innovation network acts as an intermediary and disseminates rural innovation, so can accelerate the poverty alleviation process (Saparita R. , Dyah, Abbas, \& Hidajat, 2015; Ximing Yin, Jin Chen, Jizhen Li, 2019). The function of LIS theoretically is to provide and improve infrastructure in rural areas so that community can easily access the innovations and information needed. However, LIS still lacks of relation to innovation provider such as universities and research institution, so far the need for innovation and information were obtained from local governments through technical offices, therefore it is necessary to bring community close to innovation providers.

\section{THE LOCAL INNOVATION SYSTEMS (LIS) IMPLEMENTATION}

The LIS was established through FGD (Focused Group Discussion) and Dialogue involving community representing Belu District in 2011-2012, and was proposed to the people of Bakustulama Village in 2013. LIS then underwent changes to suit the socio-economic conditions of Bakustulama Village, by involving the local community to include farmers, farmer groups, extension workers, village staffs, and The Agricultural, Fishery, Forestry and Extension Agency (AFFEA) guided by researchers of Indonesian Institute of Sciences. The LIS was agreed to be implemented in Bakustulama Village in consideration with the local farmer needs on information and innovation concerning agricultural 
activities, including government programs for farmers. In the implementation process, two farmer groups that consider as poor were chosen. First, the poor farmers so called new residents that landless because they are refugees from neighboring country, the Democratic Republic of Timor Leste (DRTL) that migrated to Indonesia, and resettled in Bakustulama Village since 2000. Second, the local farmers which are actually not that poor, they were slightly above national poverty line as they have production land that enough to fulfill their daily needs.

\subsection{Target Group 1: The New Residents}

The new residents are migrants or refugees from DRTL, around 35\% of Bakustukama village population. They were resettled by the local government in Taliren and Fatukrin hamlets of Bakustulama village in early 2000. The new residents were the very poor farmers as they were landless and have no productive activity; they were very dependent on government aid. The government support them with 0.01 ha land divided into simple housing (0.007 ha) including small yard around 0.003 ha (Figure 3) and monthly allowance around US \$ 13.412 to support their daily life which is actually not enough. These migrants were not really a farmer when they were live in their country before migrated to Indonesia. Therefore some of these migrants have become troublesome for the community by becoming mugger or tramp and disturbing the social condition in the community. But some of them also were creative enough, although they were not farmer in origin, to used their limited yard and small land along the river and local forest by planting corn as their staple food intercropping with variety of local beans (legumes) such as rice beans (Vigna umbellata), and string beans (Phaseolus vulgaris), where they plant it in one hole adopting the local farmer agricultural practice and also pigeon peas (Cayanus cayan), Those plants have different harvest time and very adaptive to dry land. They also plant cassava as they second staple food, with this system they had managed to provide food for the whole year for their family even in a small amount (Figure 2).

In general, people of East Nusa Tenggara practice this intercropping system (Hidajat \& Dyah, 2012; Carolina \& Hidajat, 2016), corn is their staple food and they cooked and mixing it with these legumes, as legumes becomes source of protein for them. In this local agricultural system, although their land is dry and can only harvest once in a year, they were managed to provide enough and good food in a year. Harvesting time for corn is 3 months, rice bean and string bean 4 months, pigeon peas 6 months and cassava around 8 to 12 months (Hidajat \& Dyah, 2012). For other needs, i.e. foods, cloth, health, etc., they rearing chicken to be sold in local market.

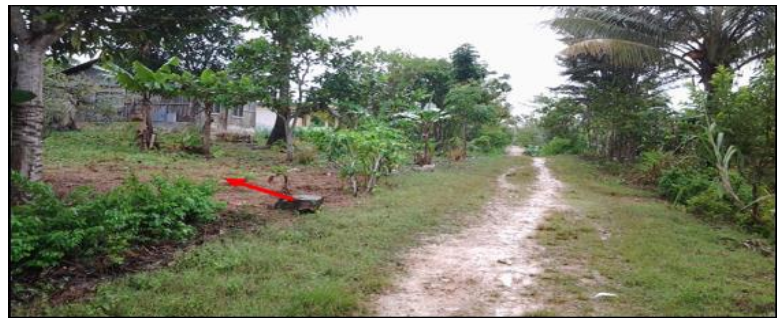

Figure 2: Housing and Small Yards of the New Residents

\subsection{Target Group 2: The Local Farmers}

The local farmer in average has 4 ha production land but only 1 ha is used. They plant corn intercropping with beans, cassava, and they plant rice, and also plant vegetables as cash crops. Some of the farmers breed cattle, especially rich farmers, while the poor are rearing chicken in their yard. Most of people's production are sell in the local small market, weekly, which is located near their village, i.e. in Halelulik Village around $12 \mathrm{~km}$, while the central market located in the district city around $19 \mathrm{~km}$. With limited access to the market, the people choose only to produce adequately. The local farmers as the target of the study are not so poor; they were slightly above the poverty line with average income per month of US \$20.123.

The production and productivity of the people actually can be increased by using appropriate technology, but with their small income they could not purchase the technology they need, also because they did not really know what kind of technology they can use (lack of information on appropriate technologies). Although, government had been disseminated many innovations or technologies throughout the country, through agricultural development program for more than 2 decades (Indraningsih, 2017), but in Belu many of those disseminated technology was not utilized (Dyah, Saparita, Abbas, Mulyadi, \& Hidajat, 2011). Many cases in Indonesia, especially in rural areas shown that generating technology is not as big problem as ensuring its utilization by the intended user (Anadon, et al., 2016). Besides the nature of the

\footnotetext{
${ }^{2}$ Surveyed conducted in early 2013 to select farmer group as the target group for implementing LIS

${ }^{3}$ Surveyed conducted in early 2013 to select farmer group as the target group for implementing LIS
} 
technology itself (expensive, complicated, and inefficient), lack of information and its availability, become obstacles for poor people to use technology they actually need. Other reason for the farmers in the location to not to use technologies that can increase their production is lack of accessibility to market for their products. Technology such as hand-tractor that can help them in tilling their dry land is too expensive. They only can rent it from other farmer that have the technology but the availability is limited and many farmers need it, so they have to queue, and they have short time for planting which will affect the quality of their products if they plant it late, so most of them prefer to do it manually.

\section{THE ROLE OF LIS IN COMMUNITY EMPOWERMENT}

The implementation of LIS in Bakustulama Village in 2013, was fully supported by the local government. When LIS was established there were six local offices involved namely: Agricultural Office, Livestock Office, Forestry Office, Fishery Office, Food Security and Agricultural Training Implementation Agency, and Regional Development Planning Agency in the district level. In the local level (Sub-District and village) it was supported by the village and the local Agricultural, Fishery and Forestry Extension Agency (AFFEA) where LIS was attached. The attachment of LIS in AFFEA was with consideration of its function as agricultural extension agency in the village and it is believed that the existence of an institution will ensure its sustainability.

The LIS here were provide the community with access to innovation and information on agriculture activities which can increase the production and productivity, so can increase their income. Here The Agricultural Office here have important role in the development of agriculture activities through several program. The agricultural development in the village was executed by providing agricultural production facilities such as seeds, fertilizers, technologies, and pesticides also extension. Fishery program is not yet developed due to lack of water availability. Forestry program was developed for community (community forest program) where the community surrounding the forest was permitted to use the land around the forest for vegetable cultivation (as intercropping crops).

The transformation of the two farmer groups after involved in LIS is shown by index number. An Index numbers is a tool that provides a simple way of representing changes over time. Each value is expressed as a percentage of a base value which is the value that occurred in a base period. The index number is a statistical indicator that expresses the proportional change in value of specific phenomenon or group of phenomena compared to specific base. It measures the changes in time and place (Jeff Ralph, Rob O’Neill, Joe Winton, 2015). For calculating index numbers there must be a base year period or a certain base time period as a guideline or benchmark (Jeff Ralph, Rob O’Neill, \& Joe Winton, 2015 ) in this case the base year period is 2012 for the first calculation in related to the year of LIS implementation in Belu. Then index number was calculated each year up to 2019, with the base time period is 2012 , for example to identify the change in 2013 the base time period is 2012, and the index number in 2014 was calculated with the base time period of 2012, and so on. The calculation referred to simple Index Number as follows (Jeff Ralph, Rob O’Neill, \& Joe Winton, 2015):

$$
I=\frac{X_{n}}{X_{o}} \times 100 \quad \begin{aligned}
& \text { Where } \mathrm{I} \text { is Index number counted } \\
& \mathrm{X}_{\mathrm{n}} \text { is the value at the time counted } \\
& \mathrm{X}_{\mathrm{o}} \text { is the value at the previous time or base time period }
\end{aligned}
$$

To interpret the change or the growth is by calculating the percentage change of the index number, in order to learn whether there is an increase, stabilizes, or decreases or in this case whether the transformation was occurs. The percentage change can illustrate how much or how significant is the change occurs, in this case the change was calculated each years with the year before as the base year. The changes that occur illustrate that the LIS have functioned in empowering the community and hence increasing their economic life. The changes that occur in the two farmer groups are illustrated by describing how LIS provides services to the two farmer groups according to the conditions and problems they are facing. The percentage change is calculated by simple equation (Jeff Ralph, Rob O’Neill, \& Joe Winton, 2015) as follows:

$$
\text { Percentage Change }=\frac{I_{l}-I_{0}}{I_{0}} \times 100 \quad \begin{aligned}
& \mathrm{I}_{1} \text { is the index number at the time counted } \\
& \mathrm{I}_{0} \text { is the index number at the previous time or } \\
& \text { base time period }
\end{aligned}
$$

\subsection{LIS and The New Residents}

Understanding the existing condition of the new residents, the extension workers as the element of LIS was seeking the availability of land for them so they can carry out production activities. Through the extension worker's connection, 
the new residents get access to production land that was lent by local land-lord, where they could not get it before because of their status as refugees. As refugees, they have not been trusted by the local people yet. Through extension worker, where they are trusted by the local people, the access for agricultural land becoming open to these new residents, as the extension worker provide guarantee for them. The borrowed land (idle land) can be used only for a limited time, which is only during the dry season.

On that borrowed land they planted vegetables which have short harvest time and the demand is high enough so in a relatively short time they can get income; also they planted pineapple in their yard as an intercropped plant with corn. The Pineapple was chosen because of lack of its availability in the local market so the market opportunity was quite promising. Their activities were assisted by extension workers. This option also in consideration that the demand for vegetables is very high, all this time many vegetables was obtained from other regions, as well as the demand for fruit, i.e. Pineapple.

The obstacle in vegetables cultivation in this area is the water availability. Water for agriculture need in this area, is rely on rainwater, when there is no rain in long dry season, water availability is crucial. Actually, in the area there is a river that never dry, small amount of water is always available. But the location is lower than their agricultural land. Under such circumstances, the AFFEA and the local government lends a water pump to deliver water to the site of their agricultural land. Thus poor farmers can undertake productive activities before the rainy season when they have to return back the land to its owner, during the time they were able to get yields three times. Vegetables can be quickly sold to the local market $( \pm 12 \mathrm{~km})$ and to the middlemen that come to the village to buy their products.

For pineapple cultivation, the extension workers provide pineapple crown that they had got through their network with other extension workers in other areas. And for vegetable seeds, they have obtained it from local farmer groups. For cultivation of pineapple and vegetable, training was given by extension workers assisted by researchers from IIS. After 3 months, these poor farmers can harvest vegetables (Figure 3) and sell it to the local market. The income received by the new residents after LIS implementation through agricultural activities is shown in Figure 3.

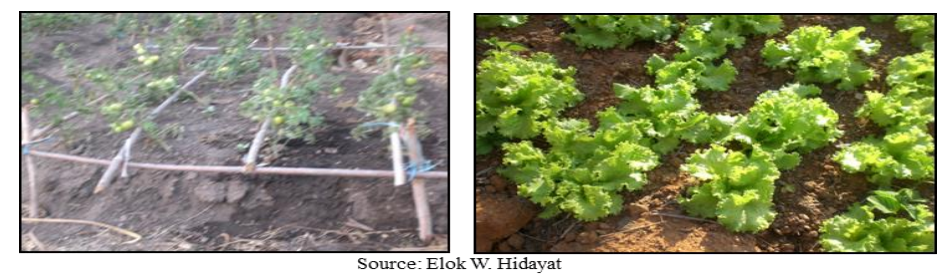

Figure 3: Utilization of dry land for vegetable cultivation

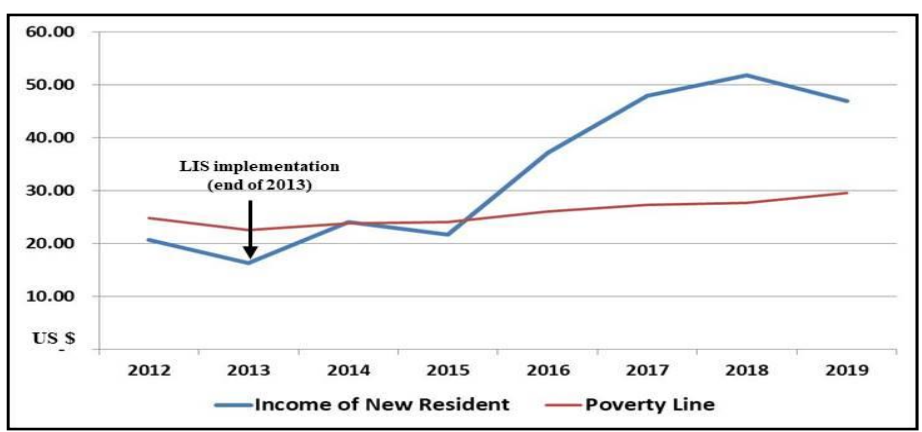

Figure 4. Increase of Income of The New Residents in Average after LIS Implementation at The End of 2013

Atter the new residents as the very poor tarmers were able to produce trom the land they borrowed, the land-owner was then wanted to do the same activities. For this reason, the borrowed land was withdrawn from the new residents. In the following season the new residents were landless again and their income was reduce although still better than in 2012-2013 (Figure 4). However, their capacity in productive activities was shown in a short time and noticed by the local government. In 2013 in about 500 hectares dry land (savanna) of Bakustulama Village was developed as ranch to provide cattle feed for local cattle breeders and the surrounding area. The land was planted with various grasses for cattle feed (Bau, 2018). However due to lack of man-power, in 2015 the new residents were offered to help in managing the land to be planted for animal feed and in return they was given 1 hectare land in the ranch for 4 farmer groups. In this land they grow corn, beans and vegetables. When harvesting, farmers get corn, beans and vegetables, while corn wastes were for animal feed, so the availability of animal feed is guaranteed. The beans planted with corn also provide nutrition for the land which will increase the land fertility (Figure 5). 


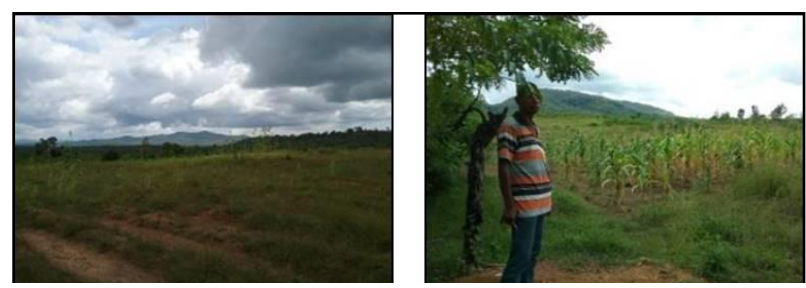

Fig. 5: Beans (left) and Corn (right) planted in ranch area

LIS through extension worker was also connected the new residents to social forestry or community forestry program, by opening access to land around the forest. On this land they had plant vegetables while also helping the local Forestry Office in protecting the forest from illegal logging. The new residents also get access to small land along the riverside provide by the local village office, where they can plant vegetables. While corn was planted as their staple food for own consumption and vegetables were planted as cash crops which gave them income for their daily needs. The open access to production land (Figure 6) gives them guarantees for food availability and becomes a source of income shown in Figure 4, however in 2019 there is a dcrease of income although there is no change of access to land production (Figure 6). During the short visit in April 2019, it is found that they experiencing crop failure due to the delay in seeds availability therefore they were late in planting. But they still have a small amount of products (vegetables and beans) that they can sell; from these products they can provide enough food for their family.

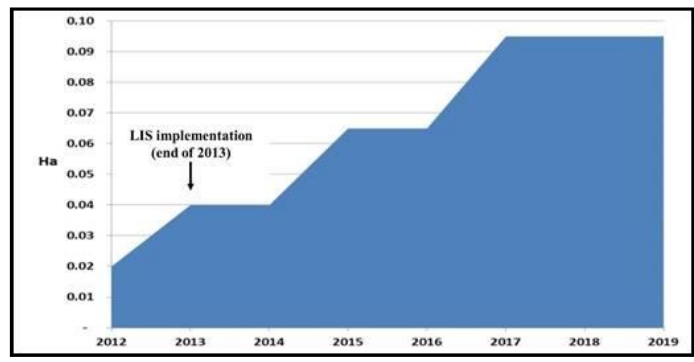

Figure 6: Access to Production Land for New Residents

\subsection{LIS and The Local Farmers}

The case was different for the local farmers as the second target group in this study, here additional income was not the main issue but increasing production and productivity are the main issues. In this case LIS can play its role in introducing the innovation needed to increase their production and productivity and its marketing. The group of local farmers involved in implementing LIS was farmers who were only able to cultivate less than half of their land, due to the climate and also limited market. But after seeing the new residents that can produce from the land that usually not cultivated during dry season, the local farmer started to cultivated some of their land that not cultivated during the dry season before supported by simple technology but manage to increase their production. The extension worker assisted by local researcher, guided them in better vegetable cultivation technology that can increase the production and through LIS they also could get more information on good agricultural cutivation technology. Here, LIS was also provide them with information on market and how they could expand their market so they could expand their cultivation area (Figure 7) and still can sell their products.

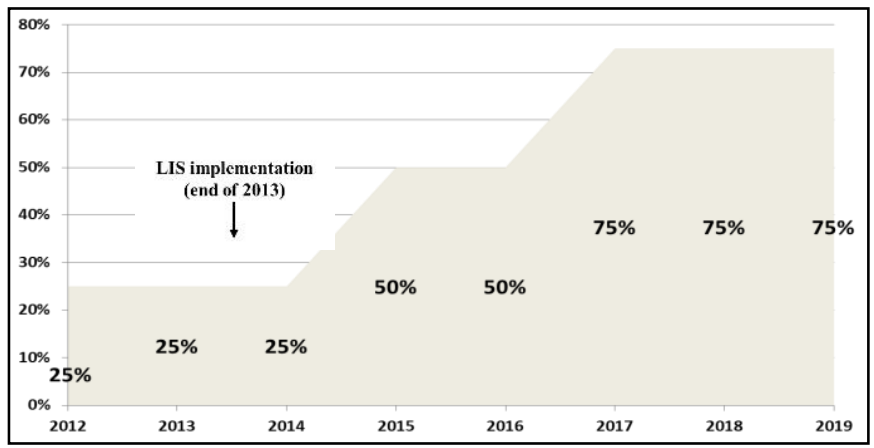

Figure 7: Increased of Land Cultivation

Other innovation for the local farmers is the pest management, in 2013 farmers in Bakustulama village faced chilli pest problems, i.e. fruit fly (Bactrocera $s p$ ). Chilli is a high economic value commodity that is widely cultivated especially peppers (Capsicum annum $L$ ) and chilli peppers (Capsicum frutescens $L$ ). This pest attack causes a decrease in 
production. Through LIS and extension worker the farmers was guided to get information to solve the problem from internet. Actually, farmers has access to internet but did not know how to get information they need. Through LIS, extension workers and assistance from researchers of IIS, farmers were able to get knowledge about how to deal with fruit flies with simple technology, and they applied it immediately and got a good result. With this fact, farmers were very enthusiastic in responding to LIS, they hope that many information can be obtained and applied to their agricultural activities. With the new knowledge on how to get information they need, they then obtained information about good vegetable cultivation and received guidance from extension workers until they can improve their production capacity.

Traditionally vegetable cultivation is done by only spreading vegetable seeds over the soil, when the seed grows there are no distance between plants; therefore the yields are not optimum in quantity and quality. With the guidance of the extension workers, they learn the technique of vegetable cultivation, starting with preparing seedlings in seedbeds and transplanting the seedlings in the permanent area that already prepared and added with compost and applying space between plants. With this technique they were able to get high yields and their production significantly increased (Figure 8), and in turn increase in income (Figure 9).

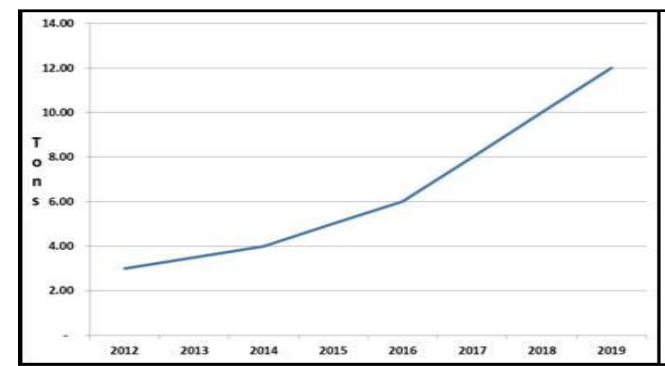

Figure 8: Increase in Production after LIS Implementation

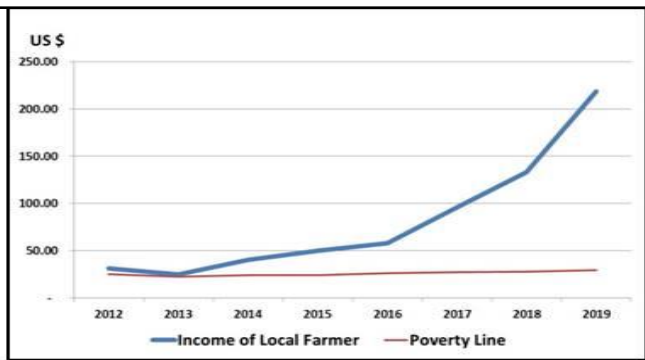

Figure 9: Increase of Income of Local Farmer after LIS Implementation

The chance to extend the area to cultivate has forced the local farmer to develop strategy in marketing their products. Extending the land to be cultivated meaning increasing production, and in addition to use technology even simple one that can increase its productivity, will give them problem in related to market to absorb their production. The reason for not cultivating all area they have before was due to limited market. But when they could increase their production, they have to expand the market, through networking that they have managed to develop in 2018. The local farmer group started to expand the market by renting a vehicle to bring their products to the markets in different areas. At first they only selling their production in two different markets near their village, and in 2019 they have managed to sell their product in 5 different markets as follows:

- $\quad$ Monday in Boas of East Malaka District around $32.2 \mathrm{Km}$

- Tuesday in Uabau of Malaka District around $37.1 \mathrm{~km}$

- Wednesday in Betun of Central Malaka District around $54.5 \mathrm{Km}$

- Thursday in Halelulik of West Tasifeto-Belu District around $12 \mathrm{Km}$

- Saturday in Loloa in Atambua of Belu District around $19.4 \mathrm{Km}$

With open access to markets other than local market (Halelulik), the local farmers could get around US\$10.914 per day after paying the vehicle rental fees. In average they could get around US \$ 218.28 per month per household which is a significant increase of income.

\section{DISCUSSION}

To assist the farmer groups, first the extension workers were mapping the need of the two target groups within LIS function, to determine the kind of assistances that they can provide. Therefore, assistances that provided were different between the two target groups. For group-1 the new residents, they assisted them to get access to production land, while for group-2 the local farmers they assisted them to get information and innovation in good farming technique and market. Although the assistances given were different between the two groups, but basically the extension workers work using their relation and interaction in the community and the local offices in Belu, that they build to support their work. Through this relation and interaction with other farmer groups and staffs from different offices that responsible for rural development program, the extension workers got innovation, information and program that can be used by the farmers.

The assistances that were provided to the two farmer groups has changes them. The changes occur were for the better condition for the two groups, and the transformation that was hoped to occurs are:

1. The New Residents: get access to production land and can earn income so they can increase their economic life from very poor farmer becoming not so poor farmer 
2. The Local farmers: get access to information and innovation to increase their capacity which is extent the land to cultivate and increase in production and productivity, and also expand the market so they can also increase their income, and transform them from not so poor farmer becoming a little more prosperous (better income).

The transformation of the two groups were analyzed by evaluating the income received before and after the LIS implementation. For the new resident the income received were correlate with the access to production land. While for the local farmer the income received were correlate with the extend of cultivated land and increase in production and productivity, and also extend in market. To learn how significant the changes are, an index number were calculated continue with percentage change to determine how significant is the change.

During the implementation period, there were significant change that greatly affected the existence of LIS and could not be avoided, namely change in government policy. In 2016 the government issued a new policy that drew extension workers back to their technical agencies in the district cities, and AFFEA was slowly abandoned and affected the existence of LIS. With this new policy, the LIS as institution was no longer exist. This condition occurs because LIS as the intermediary institution was attached to AFFEA. Meanwhile, the innovation system at the district level which according to the agreement was the responsibility of the Food Security and Extension Office in District level also did not function since the beginning of LIS implementation.

The attachment of LIS at AFFEA in the beginning of implementation program was considered very appropriate because it is close to users of innovation, in this case farmers, and also because its facilities were considered sufficient to meet the minimum requirement of innovation systems, and it was no need to build a new institution. Building a new institution will take a long time also in consideration that there was no financial support. But when there was a change in policy from the central government, this condition was no longer supportive.

Actually the implementation of the new policy is different in each region, but in Belu the impact is that all AFFEA staffs were positioned in the district city and no longer among the community, and hence activity in rural area were become rare and discontinued. Extension activities are still continued to assist farmers along with the program from District Government through technical Offices, however with this new policy there is no propose program from the community (farmer groups) or village staffs as before where they could propose a program through AFFEA. All the program for farmers now coming from the government (top down).

Beside activities, LIS facilities were also declining, in fact it was not established yet but was already abandoned. On the other hand, the number of personnel serving as extension workers has increased, except they are not working in the scheme of innovation systems but just running the activities of their office.

\subsection{LIS Empowering The New Residents}

Their participation in LIS implementation in 2013 had given them access to land that they can cultivate. This access was open by extension worker that was managed to connect the poor farmer to local land-lord that have uncultivated land due to limited labour and dry season. During dry season usually people in Belu only use part of their land (25\% - 50\%) because of lack of technology and also limited market. Here the extension worker was assisted the poor farmer to negotiate in order to be able to used their land, which is succeeded and they could borrow around 0.5 ha land to be cultivated during dry season, in rainy season the land owner will took back the land and used it for paddy cultivation. The open access to production land has given them opportunity to earn income. Although the land-owner then took back the land they borrowed, but another opportunity has comes from local government by involving them in development program. The local government involved them in the program was after observing their capacity in conducting productive activity. Even in a short time, the new residents have shown that they can be productive if they have a chance.

To analyse the transformation or change of the new residents, index number was calculated with 2012 as the base year and the percentage change calculated each years to learn the transformation occurs (Table 1). From Table 1, shown that the change occurs each year, and in 2014 a significant change has occur (39.98\%) where in this year the new resident start to involved in the ranch development. In this activity, the new residents received 1 ha land in the ranch to be work on. On this land they plant corn, vegetables and beans. Corn is grown as staple food, while vegetables and beans were grown as cash crops where they earn their income. However, in 2015 there is decline in their income received due to long dry season, in this season their production is not optimum. But in 2016 there is a significant change $(67 \%)$ which also shown by increase in income which mostly comes from vegetables, while corn and beans mostly for own consumption. However the change of government policy in 2016 which limited the assistances from extension worker had influenced the performance of the new residents, as they were not farmer in origin. The lack of assistances from extension worker affected their production which shown by index number in 2019, due to the unpredictable climate and they were facing crop failure especially for corn, but they still got enough income from vegetables and beans. The negative (-) sign here was showing that there was a decrease of income received. But the decrease was not made them back under poverty line. Therefore, they are still optimistic and eager to continue their work on the farm. The decline in production that occurred was admittedly because they were unable to adapt to the climate and lack of assistance from extension worker, in contrast to local farmers who did not experience crop failure. 
Table 1. Index number of incomes received by The New Resident

\begin{tabular}{c|c|c|c}
\hline Years & Average Income $(\boldsymbol{U S ~ \$ )}$ & I (Index Number \%) & Percentage Change (\%) \\
\hline 2012 & 13.45 & 100.00 & 0.00 \\
2013 & 14.00 & 104.09 & 4.09 \\
2014 & 20.17 & 149.96 & 44.07 \\
2015 & 20.10 & 149.44 & -0.35 \\
2016 & 33.62 & 249.96 & 67.26 \\
2017 & 50.44 & 375.02 & 0.60 \\
2018 & 67.25 & 500.00 & 33.33 \\
2019 & 60.00 & 446.10 & -10.78 \\
\hline
\end{tabular}

Base on the income received, they still need assistance from the extension worker to increase their capacity in agricultural practice. Unfortunately they are not adopting the local farmer practice in intercropping system. Practice in intercropping system was applied when they are only having a small-land (i.e. yard) to cultivate. As now they have larger land to cultivate, they tend not to practice the intercropping system; they plant corn and beans in different area (Figure 5). The practice applied by the new residents was actually not given them optimum production in total. The explanation was that if they apply the local intercropping system, where they plant beans in the same location with corn, in this case they only divide their land for corn area and vegetable area and they still have three crops, corn, vegetables and beans. The calculation is roughly illustrated as follows:

A. Traditional intercropping system practice by local farmer:

From 1 ha land divide into two cultivation area:

$1 / 2$ ha for corn and beans

$1 / 2$ ha for vegetables
Yields:

corn $=0.08$ tons

beans $=0.05$ tons

vegetables $=6$ tons

B. Cultivation applied by the new residents:

From 1 ha land divide into three cultivation area:

$1 / 3$ ha for corn

$1 / 3$ ha for beans

$1 / 3$ ha for vegetables

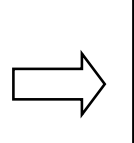

Yields:

corn $=0.02$ tons

beans $=0.03$ tons

vegetables $=2.67$ tons

The illustration shows that the traditional intercropping system is actually more appropriate for local condition which have dry climate and dry land. Planting legumes helps improve soil fertility. The traditional system (A) gives better results than growing the crops separately as is done by the new residents (B). Overall, LIS was able to help the new residents to carry out agricultural activities and obtain sufficient income for their families, Figure 10 illustrate how LIS empowering the new residents by opening access to obtain production land so that they have source of income.

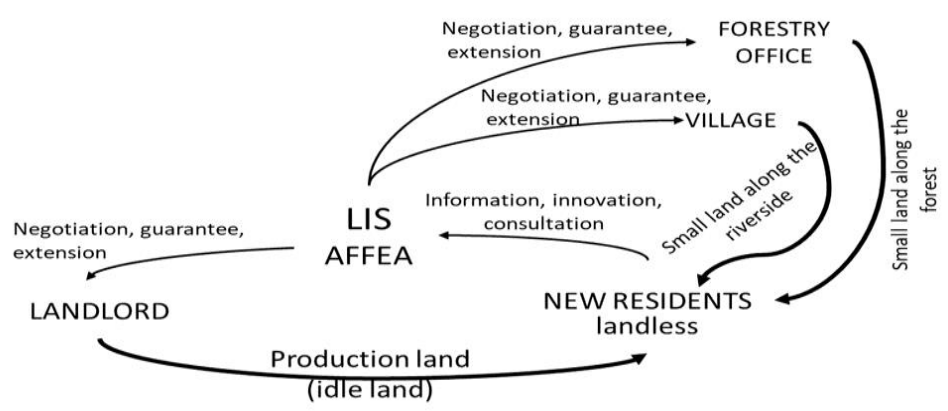

Figure 10: LIS Opening Access to Production Land for New Residents

\subsection{LIS Empowering The Local Farmers}

When the new residents are able to produce from the land they borrowed, the local farmers start working on the part of their land that is usually not cultivated supported by simple technology but manage to increase their production. Figure 7 shown changes in land use activities of local farmers starting in 2014. In 2012 up to the end of 2013, they only cultivated 25\% of their land. The LIS was implemented at the end of 2013, and at the beginning of 2014 referred to the new residents that managed to make use of the idle land (borrowed land), they began to work on land that had not been 
cultivated so far. In 2015-2016 they worked on 50\% of their land area and economically give them significant results in production and income they have received (Figure 8 \& 9) and therefore in 2017-2018, the area of cultivated land has increased by $75 \%$.

The change occur in local farmer during the implementation of LIS shown by index number and percentage change in Table 2. The change occurs each years and tend to increase up to 2019. In 2019 a tremendous change occurs because the local farmer manage to expand market for their production which increase their income around $65 \%$. With this change the farmer have high hope for LIS to assist them in productive activity (agriculture development).

Table 2. Index number of incomes received by The Local Farmers

\begin{tabular}{c|c|c|c}
\hline Years & Average Income $(\boldsymbol{U S} \boldsymbol{\$})$ & $\begin{array}{c}\text { I (Index Number } \\
\text { \%) }\end{array}$ & Percentage Change (\%) \\
\hline 2012 & 41.16 & 100.00 & 0.00 \\
2013 & 48.68 & 118.27 & 18.27 \\
2014 & 61.19 & 148.66 & 25.70 \\
2015 & 68.74 & 167.01 & 12.34 \\
2016 & 100.84 & 245.00 & 46.70 \\
2017 & 137.48 & 334.01 & 36.33 \\
2018 & 194.38 & 472.25 & 41.39 \\
2019 & 320.51 & 778.69 & 64.89 \\
\hline
\end{tabular}

their production and productivity. Because market become obstacle to extend the used of their land optimally, expanding market is one of LIS priority to help the farmers. By opening access to rent vihicles to bring their production to the market, the local farmer

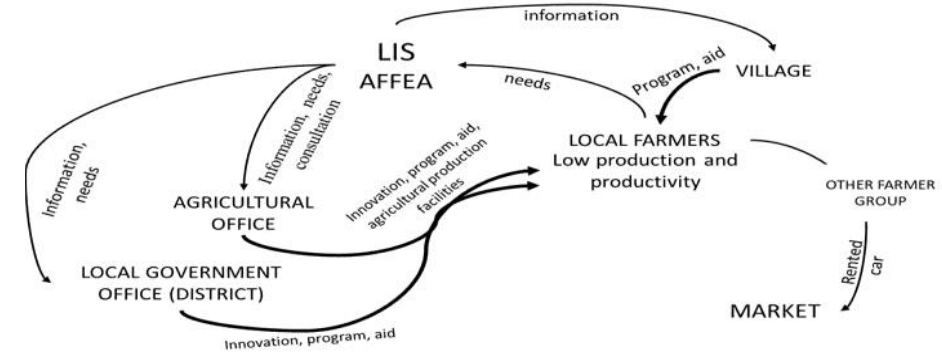

Figure 11: LIS Opening Access to Innovation and Information for Local

manage to expand up to five (five) market in different area. Therefore, the local started to expand cultivated area from from $50 \%$ up to $75 \%$. Figure 11 illustrate how LIS empowering the local farmer by opening access to information and innovation to increase their production and productivity, and opening the chance in expanding market.

\subsection{LIS of Bakustulama}

LIS in Bakustulama Village institutionally has no longer exist, after the new policy was issued. The new policy drew extension officers back to their Technical Office in the district city and their positions were no longer at AFFEA. This condition has caused BPP to be left behind, and currently its functions just like a transit point for extension workers when visiting farmers. Extension workers still continue to make visits, although not as often as before, and the farmer feel it is not enough. seek Thus to meets their needs, they seek for themself by using the network that was established before.

During the implementation period, the farmers had learned how to get the information they needed via the internet and they were able to use it. In addition, the network that was built during the implementation period is still function even LIS institution is not exist anymore. The community can still make benefit of the network to get the information they need. In this case, the extension workers still give assistant but not as often as before. Because of the benefits felt during the implementation period, the community is still trying to maintain the system, especially the network that has been built. This happened due to the active participation of the chairman of the farmer groups association supported by the head of the farmer group. With this network, farmer groups are able to obtain various development programs from the government. The performance of farmer groups is an important factor in gaining government trust in implementing rural development programs.

The case in Bakustulama Village shows that the existence of an institution cannot guarantee the sustainability of a program. Initially, it was assumed that institution was needed to ensure the sustainability of a program (Uphoff, 1992; Norman Uphoff \& Louise Buck, 2006). However, it turns out that the institutions that depend on the government cannot guarantee sustainability. Due to dependence on the government, any change in policy will have an impact on the institutions in the village level, as happened in Bakustulama Village. However, the case in Bakustulama Village shown that institutions that are less dependent on the government, in this case community-based, will be more sustainable. 
Institutionally LIS is no longer exist, but the mechanism is still working in the form of network driven by farmer groups. The network established during the LIS implementation period had gave great benefit to farmers, and therefore they still maintaining and functioning the existing network.

\section{CONCLUSION}

The case in Bakustulama Village shows that local innovation systems has important role in community empowerment. From the implementation at the end of 2013, the systems was utilized by the community until 2016 when the government issued a new policy. The new policy affected LIS existency does not make the community leave the system that has been built. Even though the LIS does not exist institutionally, the mechanism in the form of a network is still functioning and providing benefits to the community.

The benefits felt by the community were shown by the progress of the two groups involved in LIS implementation. The benefit felt by the new residents was that they obtained cultivated land and were trusted to be involved in running government programs, namely the ranch development program in Bakustulama Village. Their involvement in ranch development program is the impact of their performance when participating in LIS implementation. During that time they demonstrated that they were able to carry out productive activities if given the opportunity, namely having access to production land. Although the results are not optimal, because they are not farmers in origin, but they have motivation to learn. Therefore, the role of extension workers is very important to assist them. This condition shown when they were experienced crop failure in 2019 because late in starting planting. Late in planting was due to not being able to read the climate, in contrast to local farmers who are able to adapt to the climate and they were not experienced crop failure. Likewise with the agricultural system they had applied which adheres to a monoculture system as is done in other regions. This is actually not a problem, but considering the dry soil with a dry climate, adaptations are needed in order to give optimal results. In this case, the traditional planting system, namely intercropping with legumes, can provide optimal results on dry land.

For the new residents all the opportunity to use land available was open through the connection of extension worker. In general, after the implementation of LIS, the new residents as the very poor farmers have access to production land and hence their income is guaranteed. Additionally, their involvement in productive activities is at the same time a solution for the local government in dealing with the problem of refugees, where before many of them were causing social problems because they have no income.

Meanwhile, the benefits felt by the local farmer were increased of production and productivity. Besides that, with the information and innovation they could get from the network, they can make better use of the land than before. Previously, only about $25 \%$ was used, now $75 \%$ has been cultivated and still they can sold it in the market as the market also has been expanded. Before they could not sell their excess product due to limited market, and by utilizing the network, market can be expanded so that they can sell their agricultural products.

When local farmer groups are able to increase their capacity by expanding their agricultural land and markets, their status has increased from subsistence farmers to entrepreneur farmers. Therefore this group is no longer the target of agricultural extension activities. In 2019, this group no longer received assistance from agricultural extension workers, instead they have to be very active in search for information and innovation that they can use in their activity. This activity was drive by the head of the farmer group that also encourage the farmers to use the information and innovations that have an impact on their production activity.

Through the case in Bakustulama Village, an innovation system developed in accordance with social and environmental conditions is needed. When the institutions that depend on the government no longer exist due to policy changes, the innovation system mechanism can still function. The Bakustulama case shows that institutions that rely heavily on the government are vulnerable to change and do not guarantee sustainability. What keeps the system functioning is the existence of an institution at the village level, namely the farmer groups. The farmer group maintains the system because it benefits. Institution is needed, but community-based can provide assurance for sustainability.

Although LIS has not been able to encourage the growth of local innovation, because at the village level the access and facilities (i.e. research institutes, innovation providers) that support the growth of innovation. are very low. But what is important and needs to be developed is the network and free flow of information related to innovation and innovation providers. Therefore people can easily get innovation they needs and take advantage of it and in turn it will open up opportunities for the growth of local innovation.

\section{ACKNOWLEDGEMENT}

This research was made possible through support from Indonesian Institute of Sciences, and the Government of Belu District of East Nusa Tenggara Province-Indonesia. Studi ini juga dapat dilaksanakan berkat dukungan teman-teman dari NTT serta masyarakat yang terlibat aktif dalam pengembangan LIS di Desa Bakustulama, para Petugas Penyuluh Pertanian. We particularly wish to thank Elok W. Hidajat for supporting in the fieldwork, monitoring and evaluating the 
work which contributed to the learning of how LIS running in fulfilling its function to assist the community in Bakustulama Village..

\section{REFERENCES}

Anadon, L. D., Chan, G., Harley, A. G., Matus, K., Moon, S., Murthy, S. L., "Making technological innovation work for sustainable development" in. Proceedings of the National Academy of Sciences of the United States of America, 113 (35), pp. 9682-9690, 2016.

Bau, S. B. "Sonis Laloran Menuju Pengembangan Ternak Berbasis Ranch: Investasi Percepatan Pembangunan Kawasan Peternakan Terpadu" (Sonis Laloran Towards Ranch-Based Livestock Development Investment in the Acceleration of Integrated Farm Area Development). Kilas Timor. Atambua, Kabupaten Belu, East Nusa Tenggara, Indonesia. Retrieved March 4, 2020, from https://kilastimor.com/2018/04/sonis-laloran-menujupengembangan-ternak-berbasis-ranch-investasi-percepatan-pembangunan-kawasan-peternakan-terpadu, $\quad 2018$, April 21.

Berdegué, J. A., \& Escobar, G, "Rural Diversity, Agricultural Innovation Policies and Poverty Reduction", Agricultural Research \& Extension Network(22), pp. 1-16, 2002, July.

Carolina, \& Hidajat, E. W., "Kajian Agroekologi terhadap Strategi Pemenuhan Kebutuhan Pangan Masyarakat di Kabupaten Belu Nusa Tenggara Timur" (Agroecological Appraisal of Community Food Security Strategy in the District of Belu East Nusa Tenggara), Jurnal PANGAN, 25(2), 83 - 94, 2016, August.

David J. Spielman, Kristin Davis, Martha Negash \& Gezahegn Ayele, "Rural innovation systems and networks: findings from a study of Ethiopian smallholders". Agriculture and Human Values, 2011, vol. 28, issue 2, 195-212., 195212,2011

Dyah, S., Saparita, R., Abbas, A., Mulyadi, D., \& Hidajat, E, "Inovasi dan Kemiskinan" (Innovation and Poverty), ( B2PTTG-Subang), 2011.

Food and Agriculture Organization, "Technology and Its Contribution to Pro- poorAgricultural Development", UK Department. FAO, 2016.

Hermanto, "Pengentasan Kemiskinan di Perdesaan: Pengembangan SDM, Penguatan Usaha, dan Inovasi Pertanian" (Poverty Reduction in Rural Areas: Human Resouce Development, Business Strengthening and Agricultural Innovation). Forum Penelitian Agro Ekonomi, 35(2), pp. 139-150, 2017, December 2.

Hidajat, E. W., \& Dyah, S., "Traditional inter-cropping system practice in supporting family food security at Belu, East Nusat Tenggara Province, Indonesia". In Proceedings of International Seminar on Enhancing Grassroots Innovation Competitiveness for Poverty Alleviation, pp. 244-249, LIPI-Yogyakarta: 2012.

Indraningsih, K. S., "Strategi Diseminasi Inovasi Pertanian Dalam Mendukung" (Agricultural Innovation Dissemination Strategy in Supporting Agricultural Development). Forum Penelitian Agro Ekonomi , 35 (2), pp. 107-123, (2017, Desember).

Javed, Z. H., Farooq, M., \& Ali, H., “Technology Transfer And Agricultural Growth In Pakistan”, Journal of Agricultural Science, 47(1), 82-87, 2010.

Jeff Ralph, Rob O'Neill, \& Joe Winton. A practical introduction to index numbers. Chichester, West Sussex, United Kingdom: John Wiley \& Sons, Ltd, 2015

Mbagwu, F. C., Benson, O. V., \& Onuoha, C. O, "Challenges of meeting information needs of rural farmers through internet-based services: experiences from developing countries in Africa. Kuala Lumpur, Malaysia". Retrieved March 3, 2020, from http://library.ifla.org/2195/1/166-mbagwu-en.pdf, 2018.

McCulloch, N., Weisbrod, J., \& Timmer, C. P., "Pathways out of poverty during an economic crisis: An empirical assessment of rural Indonesia". Jakarta, Indonesia. Retrieved March 3, 2020, from https://www.econstor.eu/bitstream/10419/31967/1/534767672.pdf, 2007

Natawidjaya, R. S., Bachrein, S., Sinaga, A., Perdana, T., Sugandi, D., \& Budiman, "Analisis Sistem Inovasi dan Divusi Teknologi pada Agroekologi Padi Sawah di Jawa Barat" (Analysis of Innovation Systems and Technology Diffusion on Ricefield Agroecology in West Java). Bandung: Ministry of Agriculture and University of Padjadjaran, 2007. 
Norman Uphoff \& Louise Buck, "Strengthening Rural Local Institutional Capacities For Sustainable Livelihoods And Equitable Development", Washington DC, USA, 2006.

Parke, C., "Impact of Technology on Agriculture and Food Production", Retrieved April 21, 2020, from https://www.researchgate.net/publication/285249181_Impact_of_Technology_on_ Agriculture and_Food_Production, 2015.

Saparita, R., Dyah, S., Abbas, A., \& Hidajat, E. W., "Membangun Sistem Inovasi Untuk Kesejahteraan Masyarakat" (Building Innovation Systems for Community Welfare). Jakarta: LIPIpress, 2015.

Saparita, R., Dyah, S., Mulyadi, D., \& Hidajat, E. W., "Model Sistem Inovasi dalam Penanggulangan Kemiskinan" (Innovation Systems Model in Poverty Alleviation). Jakarta, Indonesia: LIPI Press, 2012

Statistic Indonesia, "The percentage of poor people in September 2019 dropped to 9.22 percent", Retrieved April 13, 2020, from Statistic Indonesia: https://www.bps.go.id/pressrelease/2020/01/15/1743/persentase-pendudukmiskin-september-2019-turun-menjadi-9-22-persen.html, 2020.

Thirtle, J. P., "Agricultural R\&D, technology and productivity", Philosophical Transactions of The Royal Society B Biological Science, 365(1554), 3035-47, 2010

Uphoff, N., "Local Institutions and Participation for Sustainable Development", GATEKEEPER SERIES No. 31, International Institute for Environment and Development, 1992.

Ximing Yin, Jin Chen, Jizhen Li, "Rural innovation system: Revitalize the countryside for a sustainable development", Journal of Rural Studies, 1-8, 2019. 